\title{
Teacher's Preparation of Lesson Plans in English For Occupational Purposes (EOP) Through Google Classroom
}

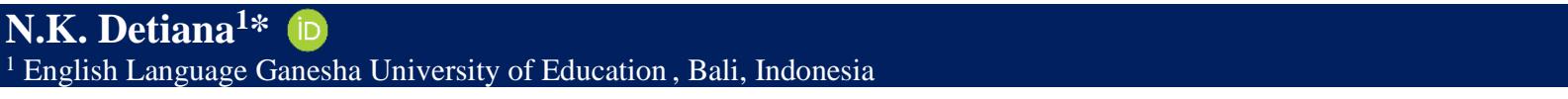

\section{A R T I CL E I N F O}

Article history:

Received March 05, 2021

Revised March 08, 2021

Accepted June 17, 2021

Available online August 25, 2021

Kata Kunci:

Persiapan guru, RPP,

masalah, Google Classroom

Keywords:

Teacher's preparation, lesson

plan, problems, Google

Classroom

DOI:

http://dx.doi.org/10.23887/jpbi.v9i 2.34426

\begin{abstract}
A B S T R A K
Dalam penerapan pembelajaran online terjadi beberapa permasalahan. Salah satu masalah yang sering ditemukan yaitu kendala fasilitas belajar. fasilitas yang dimiliki siswa kurang memadai untuk melaksanakan pembelajaran online sehingga berdampak pada pembelajaran online tidak berjalan maksimal. Penelitian ini bertujuan untuk mengukur kemampuan guru EOP dalam menyusun RPP siswa EOP melalui Google Classroom di Sekolah Menengah Kejuruan (SMK) serta untuk mengidentifikasi permasalahan guru dan menyelidiki permasalahan yang dihadapi siswa dalam pembelajaran EOP melalui Google Classroom. Jenis penelitian ii yaitu kualitatif. Penelitian dilakukan dengan menggunakan desain embedded mixmethod. Partisipan dari penelitian ini adalah seorang guru bahasa Inggris dari siswa kelas sepuluh dan 76 siswa. Metode yang digunakan untuk mengumpulkan data yaitu observasi, wawancara, dan kuesioner. Teknik yang digunakan untuk menganalisis data yaitu analisis statistic kualitatif dan kuantitatif. Hasil penelitian ini menunjukkan bahwa guru kurang, dan mengalami masalah dalam tiga aspek. Ketiga aspek tersebut adalah relevansi metode pembelajaran, relevansi evaluasi dan indikator pembelajaran, serta relevansi instrumen dan teknik evaluasi. Selain itu, siswa EOP menemukan permasalahan pada 6 aspek pembelajaran EOP melalui Google Classrooms. Implikasi penelitian ini yaitu pembelajaran EOP melalui Google Classroom dapat diterapkan oleh guru dalam pembelajaran online.
\end{abstract}

\section{A B S T R A C T}

In the application of online learning, there are several problems. One of the problems that are often found is the problem of learning facilities. Students have inadequate to carry out online learning facilities so that the impact on online learning does not run optimally. This study aims to measure EOP teachers' ability to prepare EOP students' lesson plans through Google Classroom in Vocational High Schools (SMK) and identify teacher problems and problems faced by students in EOP learning through Google Classroom. The type of research ii is qualitative. The research was conducted using an embedded mix-method design. The participants of this study were an English teacher of tenth-grade students and 76 students. The methods used to collect data are observation, interviews, and questionnaires. The technique used to analyze the data is qualitative and quantitative statistical analysis. The results of this study indicate that teachers are lacking and have problems in three aspects. The three aspects are the relevance of learning methods, evaluation and learning indicators' relevance, and instruments and evaluations' relevance. In addition, EOP students found problems in 6 aspects of EOP learning through Google Classrooms. This research implies that EOP learning through Google Classroom can be applied by teachers in online learning.

This is an open access article under the CC BY-SA license. Copyright (C) 2021 by Author. Published by Universitas Pendidikan Ganesha.

\section{INTRODUCTION}

Currently, Indonesia is implementing the 2013 curriculum (Kurniaman \& Noviana, 2017; Wulandari, 2020). The 2013 curriculum is a national curriculum design in the learning process using a scientific approach (Astiningtyas, 2018; Lestari, 2018; Subagia \& Wiratma, 2016). The 2013 curriculum is also applied in vocational high schools (Rosy et al., 2018; Saputra et al., 2018). One of the subjects obtained in vocational high schools is English. Learning English is obtained by students to improve students' language skills (Hong et al., 2015; Lou et al., 2013; Wichadee, 2011). In addition, by learning foreign languages, students can listen, speak, read and write well (Ling et al., 2014; Liu et al., 2021).

Before Covid-19, learning English for Occupational Purposes (EOP) was carried out face-to-face in the classroom. However, due to the pandemic, learning is carried out through online or online learning platforms (Olonade et al., 2021; Shah et al., 2020). The impact of technological advances affects the learning model in 
EOP. During the Covid-19 period, all types of learning in schools implemented an online system including EOP in SMK and used applications, namely Zoom, Google Meet, Google Classroom, Schoology, Webex, and so on (Ali \& Maksum, 2020; Mpungose, 2021; Yulando et al., 2019). Both online learning and blended learning must use technology. The use of online learning platforms is relatively new for EOP teachers and students in vocational schools, particularly in Bali. However, in its application, there are several problems in online learning activities. One of the problems that are often found is the problem of learning facilities. The findings of previous research also stated that one of the problems that often occur when doing online learning is that the facilities owned by students are inadequate (Dewi, 2020; Fitriyani et al., 2020; Widiyono, 2020). Other research findings also state that online learning requires a large quota, so parents need more money, but some do not work because of COVID-19 (Sadikin \& Hamidah, 2020; Zhafira et al., 2020).

This problem is also found in vocational high schools. Based on the results of observations made at SMK Negeri 2, Singaraja also carried out online learning during the covid-19 pandemic. Based on the results of the interviews, it was found that some students experienced several obstacles in terms of facilities and technical problems, especially in having a desktop/laptop/mobile phone, logging into Google Classroom without difficulty or help from others, using an account to login, choosing an account to login, joining a class. Switch between accounts, connect without problems, post comments via Google Classroom, Uncomment after posting via Google Classroom, find problems with emails, either sending or receiving emails, submit assignments via Google Classroom, get attachments or handouts from teachers, use inappropriate language wrong, understand EOP through Google Classroom, like EOP through Google Classroom, are motivated in EOP through Google Classroom, understand positive EOP through Google Classroom, understand the flexibility of EOP through Google Classroom, and perceive EOP positively with learning materials, examples or illustrations. These have an impact on the lack of concentration of students in learning. In addition, students also find it challenging to learn so that it impacts students' declining abilities.

In this case, the teacher must prepare for online learning carefully (Laksana, 2020; Tchen et al., 2018). In conducting online learning, the teacher must plan effectively the limited time he has in delivering the material. In this case, the teacher can prepare a quality lesson plan and arrange specific learning steps (Lage-Cala et al., 2020; Syauqi et al., 2020). Teachers can determine learning objectives that have been adjusted to the availability of time. In organizing online learning, compiling a balanced online learning schedule is an essential part of planning online learning every week in a planned manner with time limits and subject matter content that does not burden students (Suwannaphisit et al., 2021; J. Y. Wu \& Cheng, 2019). The online learning process will run effectively if supported by the availability of supporting media (Hartini et al., 2017). Teachers must design effective online learning designs by choosing the proper use of media devices and online applications according to the abilities and availability of facilities students own at home (Hamilton et al., 2020; Sutarto et al., 2020). The ability of EOP teachers in compiling lesson plans successfully through Google Classroom is related to the ability to correlate learning indicators with essential competencies, the ability to correlate learning materials and learning indicators with essential competencies, the ability to correlate learning methods, the ability to correlate learning procedures or steps in EOP the ability to evaluate learning indicators, abilities correlate evaluation instruments and techniques, ability to correlate information technology with EOP, and ability to use information technology especially online learning platforms in EOP.

In addition, material selection must be planned in detail so that the material delivery process can be effective (Atmojo \& Nugroho, 2020; McGrew, 2020). Online learning is very different from face-to-face learning because the duration of time is different. In face-to-face learning, the teacher has enough time to explain the lesson to his students (Polizzi, 2020; Wei et al., 2021). To overcome this, the teacher must summarize the teaching material to digest the lesson quickly. The teaching materials that the teacher conveys can be absorbed by students rather than the material described too broadly in this online learning. The ability of teachers to express creative ideas to package and present varied online learning materials supported by the selection of the proper application media can make students more motivated, active, and enthusiastic about participating in online learning (Bradley, 2020; Yu, 2021). Responding and appreciating the results of student assignments should not be underestimated. As a teacher, you must appreciate the value of the process carried out by students.

The findings of previous research stated that teachers use Google Classroom to manage student assignments, organize classes, and accommodate student interactions. Teachers consider using Google Classroom as a helpful medium for their virtual classes (Guswara, 2020; Kurniawati et al., 2019). The findings of previous research also stated that teachers considered it only a facility that could be used for learning in the google classroom and had a significant impact on learning (Haka et al., 2020; Soni et al., 2018). There is no study on teacher preparation for lesson plans in English for work purposes (EOP) through Google Classroom. This study aims to analyze teacher preparation for lesson plans in English for work purposes (EOP) through google classroom. It is expected that teachers have thorough preparation when carrying out online learning. 


\section{METHOD}

The study was conducted by using an embedded mix-method design. the research was conducted in vocational high school (vhs) in buleleng sub-districts, bali, indonesia. The investigation was focused on eop learning through google classroom faced by $\mathrm{x}$ vocational high school students of smk negeri 2 singaraja. There were four majors in this vocational high school such as akomodasi perhotelan, tata boga, tata busana and tata kecantikan. The focus of this research were: 1) to measure the eop teacher's ability in preparing a lesson plan for eop students through google classroom in the vocational high school 2 singaraja, 2) to identify and understand the teacher's problems in preparing lesson plans, and 3) to investigate the problems encountered by students in learning eop through google classroom at the vocational high school 2 singaraja. The participants of this research were one english teacher of tenth-grade students and 76 students.

The object of this study was the lesson plans made by the english teacher for the tenth-grade students in smk negeri 2 singaraja. There were used three instruments of this study. the first instrument was a rating scale used to collect the data of eop teachers' ability in preparing lesson plans through google classroom. this instrument was adopted and translated from "instrumen penilaian persiapan pembelajaran undiksha 2020", and contains 8 items. The second instrument was a questionnaire used to collect the data of the problems encountered by eop teachers in preparing lesson plans through google classroom in the vocational high school. the questionnaire for teacher problems in preparing lesson plans eop through google classroom contains 8 items. The last, a questionnaire was used to collect the data on problems found by eop students in learning eop through google classroom in the vocational high school. The questionnaires consisted of technical and infrastructure problems in using google classroom as an educational tool. The questionnaire contained 20 items.

\section{RESULT AND DISCUSSION}

\section{Result}

This study found three main findings: 1) teacher's ability in preparing lesson plans were categorized into moderate category (mean score 68.70), 2) there are three problems found by EOP teacher's at SMK N 2 Singaraja, namely: in the relevance of learning method, the relevance of evaluation and learning indicators, and the last relevance of evaluation instruments and techniques, and 3) there are students problems in EOP learning through Google Classroom, namely: in connecting in the following online learning through Google Classroom, understanding, disliking, being unmotivated, perceiving the EOP online learning negatively, and perceiving positively to provide them with plenty of various learning materials, examples, and illustrations in learning EOP through Google Classroom. The finding were exposed as follow:

In preparing the lesson plans for EOP students through Google Classroom, the success rate was measured through eight aspects. The eight aspects were 1) the relationship between learning indicators with basic competencies, 2) the relationship between learning materials, learning indicators with basic competencies, 3) the relationship between learning methods or techniques with learning materials, 4) the relationship between learning indicators with basic competencies, 5) the relationship among the procedures or learning steps in EOP, 6) the relationship between evaluation and learning indicators, 7) the relationship between evaluation instruments and techniques with learning indicators, and 8) the use of Information Technology, especially the Google Classroom platform for EOP learning. The lesson plans that had been prepared by the teacher were then evaluated by two independent evaluators to ensure the reliability and validity of the measurements. The evaluation was based on Kurikulum 2013 (Kemendikbud, 2020).

The results of the evaluation were analyzed descriptively in terms of minimum and maximum scores, mean score, standard deviation, range, variance, and standard error of measurement. The descriptive statistics of the teacher's ability in preparing five lesson plans for EOP learning through Google Classroom. The minimum and maximum scores of the teacher's lesson plans were 68.40 and 69.00. Therefore, the range between the minimum and maximum score was 0.60 . The table showed that the teacher's average ability to prepare lesson plans was 68.70. Being assessed by the two evaluators, the mean score for the teachers' ability was 69.00 is the highest and followed by the teacher's ability mean score from the second evaluator was 68.70 . However, after categorizing both of them, they were in the moderate category (mean \pm 1 standard deviations or $68.70 \pm 0.42$ ). Finally, standard errors of measurement showed that only 0.30 errors were produced by the two evaluators. Therefore, the evaluation of the teacher's lesson plans could be very reliable and valid. The variability of the scores among EOP teachers was moderate (Variance Statistic was 0.180).

When analyzed every aspect for two evaluators, the EOP teachers was lack in the relevance of learning methods, the relevance of evaluation and learning indicators, and the relevance of evaluation instruments and techniques. Those are the ability of the teacher in preparing lesson plan was a lack in three aspects. While, if it was analyzed specifically, the teacher's ability in preparing lesson plans for EOP teachers faced several obstacles or problems. First, in the third aspect, the teacher got a score of 2, because the teacher was lack to connect the 
learning methods or techniques with students' characteristics and basic competency as well as learning indicators. Second, in the fifth aspect, the teacher was found to lack evaluating in terms of objectivity concerning basic competency and consistency with efficiency in terms of time, cost, and energy. The last, aspect sixth, the teacher was lack of evaluating instruments and techniques related to learning indicators and evaluating learning processes and outcomes. Conclusively, the EOP teacher was to observe the problems in finding relevant learning methods, relevant evaluation and learning indicators, and the last, relevant evaluation instruments and techniques. Meanwhile, in other aspects, namely aspects $1,2,4,7, \& 8$, the teacher got a score of 3 . It means the teacher does not fulfill one criteria contained in the rating rubric and it is concluded that the teacher was able in those 5 aspects.

In preparing lesson plans for EOP through Google Classroom, the EOP teacher found difficulties or problems. The teachers were asked to rate their ability in preparing lesson plans as objectively as possible. After doing the self-rating, they described sources or descriptions of the problem in each aspect of lesson plans. The problems or difficulties found by the teacher in preparing lesson plans for EOP through Google Classroom in SMK N 2 Singaraja. The teacher who was teaching Tata Kecantikan and Akomodasi Perhotelan found specific problems in the third, fifth, and sixth aspects, namely in the relevance of learning method, the relevance of evaluation, and learning indicators, and the last relevance of evaluation instruments and techniques. In the third aspect, the teacher was difficult to select the learning methods or techniques based on students' characteristics, basic competency, and learning indicators. In the fifth aspect, the teacher was difficult to conduct the learning evaluation, which contained the objectivity related to the basic competency and the consistency with efficiency in terms of time, cost, and energy. Meanwhile, in the last, in the sixth aspect, the teacher was hard to select the learning evaluation instrument and technique related to learning indicators and to evaluate the learning process and outcome.

If we analyzed specifically of each lesson plan, the EOP teacher encountered problems in preparing lesson plan in lesson plan I \& III. In lesson plan I the topic is about Jati Diri dan Hubungan Keluarga which was focused on writing skills. The EOP teacher encountered problems in the third and sixth aspects in the relevance of learning methods and the relevance of evaluation instruments and techniques. Meanwhile, lesson plan III, which the topic is about Expressing Intention and focused on writing skills. The teacher encountered problems in the third and fifth aspects in the relevance of learning methods and relevance of evaluation and learning indicators.

The EOP students also found difficulty in learning EOP through Google Classroom. The students' problems were probed into twenty items. Basically, the items asked them to disclose some facilitative and technical problems or difficulties in learning EOP through Google Classroom. Students found several difficulties or problems due to EOP learning through Google Classroom. Based on the average score of those five lesson plans, there were $61.31 \%$ encountered an internet connection problem. There were $67.10 \%$ who could not understand the learning well. There were $50.79 \%$ who disliked EOP learning through Google Classroom. There were 66.58 who felt less motivated in learning EOP through the Google Classroom. There were 59.21\% who negatively perceived the EOP learning through Google Classroom. There were $53.16 \%$ who felt that EOP learning through Google Classroom did not provide sufficient and various learning materials, examples, or illustrations. In conclusion, EOP students encountered problems in 6 aspects of learning EOP through the Google Classroom learning platform.

Based on the explanation above, from 20 aspects of each lesson plan, the students of SMK Negeri 2 Singaraja encountered problems in six aspects because of the learning EOP through Google Classroom. The problems in aspects ninth, in their internet connection there were 52 students in lesson plan I, there were 58 students in lesson plan II, there were 50 students in lesson plan III, there were 48 students in lesson plan IV, and there were 25 students in lesson plan V. Meanwhile, in the sixteenth aspects, 61 students in lesson plan I (writing skill) and II (writing \&speaking skills), 53 students in lesson plan III (writing skill), 49 students in lesson plan IV (reading \&writing skills), and 31 students in lesson plan V (reading skill) did not understand the learning material through Google Classroom. They could understand better if the material was explained directly. Furthermore, the problem encountered by students was in the 17th aspect in which 40 students in lesson plan I, 45 students in lesson plan II, 39 students in lesson plan III, 41 students in lesson plan IV, and 28 students in lesson plan V did not like learning EOP through Google Classroom because of the internet connection problems, the difficulty in understanding the presented material, and the difficulty in speaking or practicing English directly. The fourth problem was in the 18th aspects in which 66 students in lesson plan I, 51 students in lesson plan II \& III, 46 students in lesson plan IV, and 39 students in lesson plan V were not motivated to learn EOP through Google Classroom because they did not understand the material in the Google Classroom group. It made me lazy, bored, and stressed to learn EOP with full of tasks. The fifth problem was in the 19th aspect in which 51 students in lesson plan I, 52 students in lesson plan II, 56 students in lesson plan III, 48 students in lesson plan IV, and 18 students in lesson plan V negatively perceived the EOP learning through Google Classroom. It 
happened because they thought that the learning was lack of explanation so that it was difficult for them to understand the topics. Also, they had to focus, so they could not do other work. The last problem was in the 20th aspects in which 44 students in lesson plan I, III \& IV, 53 students in lesson plan II, and 17 students in lesson plan V felt that EOP learning through Google Classroom did not provide sufficient and various learning materials, examples or illustrations. The teacher only posted a video, a material, and sometimes in the form of text or power points with additional assignments for the students. Those are the reasons behind the sixth aspect of five lesson plans of problems in which were encountered by the students in learning EOP through Google Classroom.

\section{Discussion}

The results of the research above indicated that EOP teacher ability in preparing lesson plans of SMK Negeri 2 Singaraja was in moderate categorization. In addition, the EOP teacher was a lack in preparing lesson plans for EOP students through the Google Classroom. Learning that is not properly prepared by the teacher will affect learning (Rusdin, 2018; Wu \& Chang, 2015). Specifically, the teacher was a lack in 1) in selecting the learning methods or techniques based on teachers' ability learning materials, students' characteristics, basic competency, and learning indicators. Inappropriate learning methods will have an impact on students who feel bored in learning (Kostiainen et al., 2018; Sutarto et al., 2020). 2) in conducting the learning evaluation which consisted of the objectivity related to the basic competency and the consistency with efficiency in terms of time, cost, and energy. 3) in selecting the learning evaluation instrument and technique related to learning indicators, and evaluating the learning process and outcome. The EOP teacher's ability in preparing lesson plans through Google Classroom during the pandemic was found because she did not have any experience in using technology. Teachers must master the technology so that online learning can run optimally (Bervell et al., 2020; Laksana, 2020).

EOP teachers faced problems in preparing lesson plans through Google Classroom. The EOP teacher found difficulties 1) in selecting the learning methods or techniques based on teachers' ability, learning materials, students' characteristics, basic competency, and learning indicators. This will have an impact on the low ability of students (Chen \& Li, 2011; Yustina et al., 2020). 2) in conducting the learning evaluation which consisted of the objectivity related to the basic competency and the consistency with efficiency in terms of time, cost, and energy. This results in teachers not being able to measure students' abilities properly (Saeed \& Hammood, 2021; Tchen et al., 2018). 3) in selecting the learning evaluation instrument and technique related to learning indicators, and evaluating the learning process and outcome. Those problems were commonly faced by teachers in online learning. This problem must be addressed immediately so as not to have an impact on the low ability of students (Mulyanto et al., 2020; Pan et al., 2021).

The students of SMK N 2 Singaraja found some problems in learning EOP through Google Classroom. The problems were in (1) connecting the learning material to Google Classroom ; (2) understanding the EOP learning through Google Classroom; (3) disliking the EOP Google Classroom ; (4) being unmotivated in learning EOP through Google Classroom; (5) perceiving the EOP online learning negatively, and (6) perceiving positively to provide them with plenty of various learning materials, examples, and illustrations. In conclusion students' preferred to study EOP face to face learning rather than learning EOP through the online learning platform

\section{CONCLUSION}

EOP teachers at SMK Negeri 2 Singaraja have problems in preparing good RPP such as; in choosing learning methods or techniques based on the ability of teachers, learning materials, student characteristics, and essential competencies and learning indicators, in conducting learning evaluations that contain objectivity related to essential competencies and efficiency in terms of time, cost, and energy, and in the selection of learning evaluation instruments and techniques related to learning indicators, and evaluation of the learning process and learning outcomes. EOP students also encounter obstacles in learning EOP through Google Classroom, especially in understanding EOP through Google Classroom.

\section{REFERENCES}

Ali, M. K., \& Maksum, H. (2020). Utilization of E-Learning-Based ICT Learning Using the Google Classroom Application During the COVID-19 Pandemic. Journal of Education Research and Evaluation, 4(4), 373. https://doi.org/10.23887/jere.v4i4.29181

Astiningtyas, A. (2018). Kesiapan Guru Sekolah Dasar Dalam Pelaksanaan Pembelajaran Tematik Integratif Pada Kurikulum 2013. Primary: Jurnal Pendidikan Guru Sekolah Dasar, 7(1), 60. 
https://doi.org/10.33578/jpfkip.v7i1.5340

Atmojo, A. E. P., \& Nugroho, A. (2020). EFL classes must go online! Teaching activities and challenges during COVID-19 pandemic in Indonesia. Register Journal, 13(1), 49-76. https://doi.org/10.18326/rgt.v13i1.4976

Bervell, B., Nyagorme, P., \& Arkorful, V. (2020). LMS-Enabled Blended Learning Use Intentions among Distance Education Tutors: Examining the Mediation Role of Attitude Based on Technology-Related Stimulus-Response Theoretical Framework (TR-SR-TF). Contemporary Educational Technology, 12(2), ep273. https://doi.org/10.30935/cedtech/8317

Bradley, V. M. (2020). Learning Management System (LMS) Use with Online Instruction. International Journal of Technology in Education, 4(1), 68. https://doi.org/10.46328/ijte.36

Chen, E., \& Li, Z. (2011). On the application of multimedia technology in foreign language teaching and learning in China's colleges: Challenges, problems and implications. 2011 International Conference on Multimedia Technology, ICMT 2011, 595-597. https://doi.org/10.1109/ICMT.2011.6001903

Dewi, W. A. F. (2020). Dampak COVID-19 terhadap Implementasi Pembelajaran Daring di Sekolah Dasar. Jurnal Edukatif Ilmu Pendidikan, 2(1). https://doi.org/10.31004/edukatif.v2i1.89

Fitriyani, Y., Fauzi, I., \& Sari, M. Z. (2020). Motivasi Belajar Mahasiswa Pada Pembelajaran Daring Selama Pandemik Covid-19. Jurnal Kependidikan: Jurnal Hasil Penelitian Dan Kajian Kepustakaan Di Bidang Pendidikan, Pengajaran Dan Pembelajaran, 6(2), 165-175. https://doi.org/10.23917/ppd.v7i1.10973

Guswara, A. M. (2020). The Contribution of Google Classroom Application and Motivation to The Learning Outcomes of Web Programming. Educational Technology, 4(4), 1-9. https://doi.org/10.23887/jet.v4i4.29896

Haka, N. B., Anggita, L., Anggoro, B. S., \& Hamid, A. (2020). Pengaruh Blended Learning Berbantukan Google Classroom Terhadap Keterampilan Berpikir Kreatif Dan Kemandirian Belajar Peserta Didik. Edu Sains Jurnal Pendidikan Sains \& Matematika. https://doi.org/10.23971/eds.v8i1.1806

Hamilton, L. A., Suda, K. J., Heidel, R. E., McDonough, S. L. K., Hunt, M. E., \& Franks, A. S. (2020). The role of online learning in pharmacy education: A nationwide survey of student pharmacists. Currents in Pharmacy Teaching and Learning, 12(6). https://doi.org/10.1016/j.cpt1.2020.01.026

Hartini, S., Misbah, Dewantara, D., Oktovian, R. A., \& Aisyah, N. (2017). Developing learning media using online prezi into materials about optical equipments. Jurnal Pendidikan IPA Indonesia, 6(2), 313-317. https://doi.org/10.15294/jpii.v6i2.10102

Hong, E., Mason, E., Peng, Y., \& Lee, N. (2015). Effects of homework motivation and worry anxiety on homework achievement in mathematics and English. Educational Research and Evaluation, 21(7-8), 491514. https://doi.org/10.1080/13803611.2015.1131721

Kostiainen, E., Ukskoski, T., Ruohotie-Lyhty, M., Kauppinen, M., Kainulainen, J., \& Mäkinen, T. (2018). Meaningful learning in teacher education. Teaching and Teacher Education, 71, 66-77. https://doi.org/10.1016/j.tate.2017.12.009

Kurniaman, O., \& Noviana, E. (2017). Penerapan Kurikulum 2013 Dalam Meningkatkan Keterampilan, Sikap, Dan Pengetahuan. Primary: Jurnal Pendidikan Guru Sekolah Dasar, 6(2), 389. https://doi.org/10.33578/jpfkip.v6i2.4520

Kurniawati, M., Santanapurba, H., \& Kusumawati, E. (2019). Penerapan Blended Learning Menggunakan Model Flipped Classroom Berbantuan Google Classroom Dalam Pembelajaran Matematika Smp. EDU-MAT: Jurnal Pendidikan Matematika, 7(1), 8-19. https://doi.org/10.20527/edumat.v7i1.6827

Lage-Cala, S., Folgueras-Díaza, M. B., Alonso-Hidalgoa, M., García-Menéndezb, D., \& Fernández-Garcíab, F. J. (2020). Investigation of the effectiveness of online learning tools for energy performance certificates preparation. Energy Reports, 6, 609-614. https://doi.org/10.1016/j.egyr.2019.09.034

Laksana, D. N. L. (2020). Implementation of Online Learning in The Pandemic Covid-19: Student Perception in Areas with Minimum Internet Access. Journal of Education Technology, 4(4), 509-509. https://doi.org/10.23887/jet.v4i4.29314

Lestari, N. D. (2018). Analisis Penerapan Kurikulum 2013 Dalam Meningkatkan Kualitas Pembelajaran Ekonomi Di Sma Negeri Se-Kota Palembang. Jurnal Neraca: Jurnal Pendidikan Dan Ilmu Ekonomi Akuntansi, 2(1), 68-79. https://doi.org/10.31851/neraca.v2i1.2190

Ling, G., Powers, D. E., \& Adler, R. M. (2014). Do TOEFL iBT® scores reflect improvement in Englishlanguage proficiency? Extending the TOEFL iBT validity argument. ETS Research Report Series, 1. https://doi.org/10.1002/ets2.12007.

Liu, C., He, J., Ding, C., Fan, X., Hwang, G.-J., \& Zhang, Y. (2021). Self-oriented learning perfectionism and English learning burnout among EFL learners using mobile applications: The mediating roles of English learning anxiety and grit. Learning and Individual Differences, 88. https://doi.org/10.1016/j.lindif.2021.102011 
Lou, S.-J., Lin, T.-C., Hsin, T.-H., Shih, R.-C., \& Cheng, T.-F. (2013). Effects of Applying Blended Teaching Approach to English Sentence Translation for Vocational High School Students. Procedia - Social and Behavioral Sciences, 106. https://doi.org/10.1016/j.sbspro.2013.12.113

McGrew, S. (2020). Learning to evaluate: An intervention in civic online reasoning. Computers and Education, 145. https://doi.org/10.1016/j.compedu.2019.103711

Mpungose, C. B. (2021). Lecturers' reflections on use of Zoom video conferencing technology for e-learning at a South African university in the context of coronavirus. African Identities. https://doi.org/10.1080/14725843.2021.1902268

Mulyanto, B. S., Sadono, T., Koeswanti, H. D., Dasar, S., Wonodoyo, N., Tengah, J., Kristen, U., Wacana, S., \& Tengah, J. (2020). Evaluation of Critical Thinking Ability with Discovery Lerning Using Blended Learning Approach in Primary School. Journal of Educational Research and Evaluation, 9(2), 78-84. https://doi.org/10.15294/jere.v9i2.46135

Olonade, O. Y., Adetunde, C. O., Iwelumor, O. S., Ozoya, M. I., \& George, T. O. (2021). Coronavirus pandemic and spirituality in southwest Nigeria: A sociological analysis. Heliyon, 7(March), e06451. https://doi.org/10.1016/j.heliyon.2021.e06451

Pan, G., Shankararaman, V., Koh, K., \& Gan, S. (2021). Students' evaluation of teaching in the project-based learning programme: An instrument and a development process. The International Journal of Management Education, 19(2). https://doi.org/10.1016/j.ijme.2021.100501

Polizzi, G. (2020). Digital literacy and the national curriculum for England: Learning from how the experts engage with and evaluate online content. Computers and Education, 152. https://doi.org/10.1016/j.compedu.2020.103859

Rosy, B., Ranu, M. E., Nugraha, J., \& Handini, H. T. (2018). Pelatihan Media Pembelajaran Berbasis ELearning, Schoology Bagi Guru SMK Program Keahlian Administrasi Perkantoran Di Kabupaten Jombang Jawa Timur. Jurnal Pemberdayaan Masyarakat Madani, 2(2). https://doi.org/10.21009/JPMM.002.2.02

Rusdin, N. M. (2018). Teachers' Readiness in Implementing 21st Century Learning. International Journal of Academic Research in Business and Social Sciences, 8(4), 1271-1284. https://doi.org/10.6007/IJARBSS/v8-i4/4270

Sadikin, A., \& Hamidah, A. (2020). Pembelajaran Daring di Tenggah Wabah Covid-19. Jurnal Ilmiah Pendidikan Biologi, 6(2), 214-224. https://doi.org/10.22437/bio.v6i2.9759.

Saeed, E. M. H., \& Hammood, B. A. (2021). Estimation and evaluation of Students' behaviors in E- learning Environment using adaptive computing. Proceedings. https://doi.org/10.1016/j.matpr.2021.04.519

Saputra, H. D., Ismet, F., \& Andrizal, A. (2018). Pengaruh Motivasi Terhadap Hasil Belajar Siswa SMK. INVOTEK: Jurnal Inovasi Vokasional Dan Teknologi, 18(1), 25-30. https://doi.org/10.24036/invotek.v18i1.168

Shah, K., Arfan, M., Mahariq, I., Ahmadian, A., Salahshour, S., \& Ferrara, M. (2020). Fractal-Fractional Mathematical Model Addressing the Situation of Corona Virus in Pakistan. Results in Physics, 19, 103560. https://doi.org/10.1016/j.rinp.2020.103560

Soni, Hafid, Hayami, Fatma, Wenando, Amien, Fuad, Unik, \& Mukhtar. (2018). Optimalisasi Penggunaan Google Classroom, E-Learning \& Blended Learning sebagai Media Pembelajaran Bagi Guru dan Siswa di SMK Negeri 1 Bangkinang. Jurnal Pengabdian Untukmu Negeri, 21. https://doi.org/10.37859/jpumri.v2i1.361

Subagia, I. W., \& Wiratma, I. G. L. (2016). Profil Penilaian Hasil Belajar Siswa Berdasarkan Kurikulum 2013. JPI (Jurnal Pendidikan Indonesia), 5(1), 39-54. https://doi.org/10.23887/jpi-undiksha.v5i1.8293.

Sutarto, S., Sari, D. P., \& Fathurrochman, I. (2020). Teacher Strategies in Online Learning to Increase Students ' Interest in Learning During COVID-19 Pandemic. Jurnal Konseling Dan Pendidikan, 8(3), 129-137. https://doi.org/10.29210/147800

Suwannaphisit, S., Anusitviwat, C., Hongnaparak, T., \& Bvonpanttarananon, J. (2021). Expectations on online orthopedic course using constructivism theory: A cross-sectional study among medical students. Annals of Medicine and Surgery, 67. https://doi.org/10.1016/j.amsu.2021.102493

Syauqi, K., Munadi, S., \& Triyono, M. B. (2020). Students' perceptions toward vocational education on online learning during the COVID-19 pandemic. International Journal of Evaluation and Research in Education (IJERE), 9(4), 881. https://doi.org/10.11591/ijere.v9i4.20766

Tchen, P., Leung, L., Simpson, F., Kim-Sing, A., \& Pearson, M. L. (2018). Bridging the gap: An evaluation of self-paced online transition modules for advanced pharmacy practice experience students. Currents in Pharmacy Teaching and Learning, 10(10). https://doi.org/10.1016/j.cptl.2018.07.006

Wei, X., Saab, N., \& Admiraal, W. (2021). Assessment of cognitive, behavioral, and affective learning outcomes in massive open online courses: A systematic literature review. Computers \& Education, 163, 104097. https://doi.org/10.1016/j.compedu.2020.104097 
Wichadee, S. (2011). Developing The Self-Directed Learning Instructional Model To Enhance English Reading Ability And Self-Directed Learning Of Undergraduate Students. Journal of College Teaching \& Learning (TLC), 8(12), 43. https://doi.org/10.19030/tlc.v8i12.6620

Widiyono, A. (2020). Efektifitas Perkuliahan Daring (Online) pada Mahasiswa PGSD di Saat Pandemi Covid 19. Jurnal Pendidikan, 8(2), 169-177. https://doi.org/10.36232/pendidikan.v8i2.458

Wu, J. Y., \& Cheng, T. (2019). Who is better adapted in learning online within the personal learning environment? Relating gender differences in cognitive attention networks to digital distraction. Computers and Education, 128. https://doi.org/10.1016/j.compedu.2018.08.016

Wu, S.-C. (Angel), \& Chang, Y.-L. (Aldy). (2015). Advancing Kindergarten Teachers' Knowledge and Capabilities of Differentiated Instruction Associated with Implementation of Thematic Integrated Curriculum. Procedia - Social and Behavioral Sciences, 177. https://doi.org/10.1016/j.sbspro.2015.02.404

Wulandari, I. G. A. A. (2020). Implementation of the 2013 Curriculum Based on a Scientific Approach (Case Study at SD Cluster II Kintamani). International Journal of Elementary Education, 4(3), $422-430$. https://doi.org/10.23887/ijee.v4i3.28172

$\mathrm{Yu}, \mathrm{Z}$. (2021). The effects of gender, educational level, and personality on online learning outcomes during the COVID-19 pandemic. International Journal of Educational Technology in Higher Education, 18(1), 1-17. https://doi.org/10.1186/s41239-021-00252-3

Yulando, S., Sutopo, S., \& Franklin Chi, T. (2019). Electronic Module Design and Development: An Interactive Learning. American Journal of Educational Research, 7(10), 694-698. https://doi.org/10.12691/education7-10-4

Yustina, Syafii, W., \& Vebrianto, R. (2020). The effects of blended learning and project-based learning on preservice biology teachers' creative thinking skills through online learning in the COVID-19 pandemic. Jurnal Pendidikan IPA Indonesia, 9(3), 408-420. https://doi.org/10.15294/jpii.v9i3.24706

Zhafira, N. H., Ertika, Y., \& Chairiyaton, C. (2020). Persepsi Mahasiswa Terhadap Perkuliahan Daring Sebagai Sarana Pembelajaran Selama Masa Karantina Covid-19. Jurnal Bisnis Dan Kajian Strategi Manajemen, 4(1), 37-45. https://doi.org/10.35308/jbkan.v4i1.1981 